\title{
THE STATE OF ANALYTICAL PROCEDURES IN THE INTERNAL AUDITING AS A CORPORATE GOVERNANCE MECHANISM
}

\author{
Ana Ježovita* \\ Boris Tušek** \\ Lajoš Žager***
}

Received: 31. 3. 2018

Original scientific paper

Accepted: 10. 11. 2018

UDC 657.6

DOI https://doi.org/10.30924/mjcmi/2018.23.2.15

\begin{abstract}
Internal auditors are facing today's fast-paced business conditions that challenge them to implement adequate information technology and use analytical procedures as key audit techniques. Continuous technology improvement enables the development and application of analytical procedures that were unimaginable in the time of 'paper-based auditing'. The research idea is to investigate the level and improvements of analytical procedures by internal auditors working in contemporary business conditions in Croatia. Given that the advancement of technology supports the application of complex analytics, the investigated problem includes an analysis of coherence between available technology and applied analytical procedures. The importance of using analytical procedures can be confirmed by the positive effects these procedures have in internal auditing as they increase its effectiveness
\end{abstract}

and efficiency. In relation to this, the research also includes an investigation of the level, differences and complexity of analytical procedures used in internal audit in order to determine the current state of and prospects for improving the effectiveness and efficiency of internal audit activity in Croatia. Considering the purpose and possibilities of analytical procedures, the research examines the extent to which, measured by the analytical procedures application level, internal audit functions in Croatia are adapting to contemporary business conditions and changing professional processes. The research issues are analyzed by using the theoretical overview, guidance provided by professional institutions, and the importance that internal auditing has as a corporate governance mechanism. The research will provide insights into whether and to what extent the required methodology is respected

\footnotetext{
* Ana Ježovita, Assistant Professor, University of Zagreb, Faculty of Economics \& Business, Department of accounting, Trg J. F. Kennedy 6, HR-10000 Zagreb, Croatia, e-mail: ajezovita@efzg.hr, phone: +385-1-2383236 ** Boris Tušek, Professor (Tenured), University of Zagreb, Faculty of Economics \& Business, Department of accounting, Trg J. F. Kennedy 6, HR-10000 Zagreb, Croatia, e-mail: btusek@efzg.hr, phone: +385-1-2383195

*** Lajoš Žager, Professor (Tenured), University of Zagreb, Faculty of Economics \& Business, Department of accounting, Trg J. F. Kennedy 6, HR-10000 Zagreb, Croatia, e-mail: lzager@efzg.hr, phone: +385-1-2383139
} 
and will assess the progress of the Croatian internal auditing in a contemporary environment. The advancement of internal auditing in Croatia will be assessed by comparing research results with the global state of the profession. In addition, the research will result in the perspectives of internal audit progress related to the skills and knowledge of internal auditors regarding contemporary technology and their competence to use complex analytics in their work. The

\section{INTRODUCTION}

In today's fast-paced business environment, it is very important to manage financial, time and human resources efficiently and effectively. Contemporary business conditions impose greater expectations on and require faster actions by decision makers. In that context, internal auditors must be able to overcome those expectations in order to remain in line with management needs and stakeholder expectations. Caratas \& Spatariu (2014) stated that today's operating conditions are witnessing an increased risk environment, and internal auditors have a role to anticipate risks and identify trends in the internal control system. Respecting that, internal auditors must continuously enhance their knowledge, skills, and applied methodology to be able to keep up to date with innovations, complexity, stochasticity, and dynamism of the company. "Technology advancement is fueling innovation in every industry: Machine learning is leading to self-driving cars and smart medical devices. The Internet of Things paired with predictive analytics - is advancing the preventive maintenance of energy grids and industrial equipment. Blockchain is reinventing financial transactions and consumer product traceability. Drones are taking on roles from delivering packages to performing physical inventories, to saving lives. And the cloud, big data, analytics, research data were collected using a survey. The obtained responses were analyzed by using appropriate statistics (frequencies, proportions, Chi-Square, Kruskal-Wallis, Mann-Whitney U, Kolmogorov-Smirnov and Shapiro-Wilk tests).

Key words: analytical procedures, analytics, internal audit, internal auditors

and bots are making business processes more efficient, more agile, and more insight driven." (PwC, 2018: 3) "Technology can be used to achieve the same level of assurance but more efficiently at a lower cost, or it can be used to achieve a higher level of assurance via a more effective audit at similar cost. Technology also enables statistical techniques (for example, sampling and regression analysis) that can provide objectively quantifiable confidence levels to help build assurance. Economics has driven auditors to focus mostly on improving efficiency (achieving the same level of assurance but at lower cost). Less attention has been paid to increasing assurance at the same cost by improving effectiveness, even though that cost would buy the additional benefits of better meeting client and investor expectations and of reducing audit and reputational risk and liability." (Byrnes et al., 2015: 95) It can be expected that the availability of technology will result in the use of analytics, if internal auditors possess the necessary level of skills and knowledge. KPMG (2018) indicates that rapid change in business processes fueled by the digitalisation requires internal auditors to be experts in advanced data analytics methods. The research idea highlights the problem of using analytical procedures in assurance engagements of internal auditors in contemporary business conditions in Croatia. The research analyses the problems of the 
availability of technology that internal auditors need to perform their engagements, and of internal auditors' skills and knowledge that they need to apply to a range of different analytics. Deloitte (2018) concludes that "analytics is a perennial high-impact area for several reasons. First, beyond-thebasics analytics is the single most powerful booster of Internal Audit efficiency and effectiveness available. Second, the continuing digitalization of business generates huge quantities of data, which analytics can transform into valuable information and business insights. Third, the tools for analyzing and visualizing data are now simpler, cheaper, more available, and easier to use than ever." (Deloitte, 2018: 8) Inclusion of contemporary technology (Brown-Liburd et al., 2015; Banarescu, 2015; Byrnes et al., 2015; Cangemi, 2016; Wadhawan \& Mahajan, 2016; Tang et al., 2017; Gepp et al., 2018) and analytics (Marks, 2009; Davuzyan \& Kavut, 2005; Soileau, J. et al., 2015; Jans et al., 2014; Kopotienko, 2015; Richins et al., 2017; Moolman, 2017; Li et al., 2018) represents the only possible course that the development of internal audit activity can take. The analyzed problem is relevant as it places emphasis on the importance of internal audit to be efficient and effective with the aim that the results of assurance engagements lead to recommendations that can be applied in practice and have measurable effects.

The authors agree that effectiveness and efficiency can be improved by a more significant use of analytics in auditing (Cangemi, 2016; Chan \& Kogan, 2016; Richins et al., 2017; Singh et al., 2017; Appelbaum et al., 2018; Li et al., 2018).

The research problem is important as a requirement for the internal audit function to be effective and efficient in obtaining engagement results in the form of applicable recommendations that should have measurable effects. The authors agree that efficiency and effectiveness can be improved by a more significant use of audit analytics. In a research conducted by Protiviti (2018) the respondents ranked as the most important data analytics goals: increased efficiency $(68 \%)$, increased effectiveness $(67 \%)$, continuous auditing (63\%), increased audit coverage (59\%), increased value to business (56\%), etc. According to Spencer Picket (2003), efficiency is defined as employing resources in a way to maximize the resulting level of output, and effectiveness includes achieving set objectives of a certain activity. Efficiency and effectiveness can be enhanced by consistently applying methodological solutions and achievements that, among other requests, include analytical procedures as a relevant audit tool. The latest business conditions remove radical changes in internal audit activity, where internal auditors are forced to follow the inevitable advancement of information technology and other business factors that bring new challenges to internal auditors. "A compliance program that more intensively leverages data analytics can lead to more effective risk management and increased business transparency." (EY, 2018: 10) In this context, it is possible to highlight processes that affect internal auditors that are the result of two aspects. First, the audit object is dynamic and changeable, resulting in faster transactions, higher risks, the need for faster management responses, and everything that is intertwined with information technology. The other aspect is a consequence of the methodological requirements of the profession, which must keep track with the contemporary and changing environment. Important aspects of methodological changes relate to a need to use information technology, and in line with that to use the analytical methods as an efficient tool to analyse (big) data in order to obtain 
reliable results. In this regard, the prosperity, effectiveness and efficiency of internal auditing are closely related to the application of analytical procedures. Thus, the research problem includes the investigation into the use of analytical procedures in assurance engagements as a leverage of effectiveness and efficiency of internal audit activity. The research tries to answer the question of how and to what extent, measured by the level and complexity of applied analytical procedures, internal audit functions in Croatia are adapting to those processes. The research problem resulted in several logically related research objectives:

- determine and summarize methodological requirements regarding analytical procedures of internal auditors when performing assurance engagements

- determine entities required to establish an internal audit function in Croatia

- categorize the types of analytical procedures by complexity

- evaluate computer-assisted audit tools and techniques (CAATTs) implementation level in internal audit functions in Croatia

- investigate if internal auditors in Croatia comply with the International Professional Practices Framework and prescribed methodology for public sector entities regarding the use of analytical procedures in assurance engagements

- make conclusions on the level of using analytical procedures in the four typical phases of assurance engagements planning, performing, reporting, and follow-up

- evaluate advancement of the internal audit function in Croatia measured by the complexity of used analytical procedures by internal auditors in order to be able to evaluate internal auditors' skills and knowledge
- conclude if internal auditors in Croatia are 'traditional' or 'contemporary' measured by the diversity and complexity of used analytical procedures in their engagements.

The growth and development of a company and the changes in the business operations result from an uncertain and chaotic business environment that imposes a need for continuous improvement of management processes and corporate governance mechanisms. One of the important mechanisms is internal auditing aimed at adding value to a company. The internal audit has developed into infrastructural function, whose scope of activity is continuously developing and advancing - from assessing financial information, via testing and rating efficiency and effectiveness of internal control system, toward a new internal audit paradigm - focusing on assessing the adequacy of risk management, controls, and corporate governance. The development and effectiveness boost in achieving the objectives of the internal auditing profession are closely linked to the progress of information technology. As internal auditing and IT become inseparable, the usefulness of various analytical procedures becomes more important. In relation to this, it can be expected that future internal audit engagements will focus on anticipating possible risks in particular business areas and on proving advice to the management on risk management prospective, primarily in terms of developing and supervising adequate internal control system as an inevitable risk management instrument.

Improving the mission, purpose, objective and scope of internal auditing must be followed by using advanced technology and methodology that includes an active application of analytics to all phases and activities of auditing in order to increase the effectiveness and efficiency of internal 
auditing. Thus, it is possible to emphasize several research contributions. The obtained results will answer the question whether internal auditors in Croatia apply the required methodology in their activities regarding using analytical procedures, and in that context, it will be possible to assess if Croatia aligns with a global progress of the profession. The results will suggest if there is a need for improving knowledge and skills of internal auditors in order to increase the application of analytics in different phases of assurance engagements. In that context, the research contribution will include the results regarding the state of the education system and will indicate whether there is a need to change and improve it in order to encourage a more active use of analytics as a tool with the aim of increasing effectiveness and efficiency of internal auditing. Raising awareness of the current state of using analytics in assurance engagements of internal auditors represents the first step in making significant progress of the profession, enabling it to keep track with uncertain, dynamic and changing business conditions.

The first section of the paper includes theoretical background of the research topic by defining analytical procedures in the context of internal auditing and providing insights into the requirements of the purpose and mission of the profession and adopted methodological approaches that follow business and technology changes. In the second section, a comprehensive review of recent literature on internal audit analytics, related skills, technology and the effects of using analytical procedures in auditing is provided. The literature review examined the research problem, objectives and hypotheses presented in the third and fourth section of the paper. The following section presents the population covered by the research, sample and questionnaire design. In the sixth section, research results are presented. In the final section, research contributions and possible perspectives of the future development of internal auditing in Croatia are presented.

\section{THEORETICAL BACKGROUND}

Traditional or technology supported approach to internal auditing must be based on the adequate ethical principles, guidelines and methodology. The leading institution that encourages, promotes, advocates and enhances internal audit profession worldwide is the Global Institute of Internal auditors. The mission of the Institute is to provide comprehensive professional, educational and development opportunities, standards and other professional practice guidance, and certification programs (The Institute of Internal Auditors; 2018). The Institute publishes the conceptual framework, i.e. the International Professional Practices Framework (IPPF), which includes mandatory and recommended guidelines for internal auditors around the world. In addition to contextual and structural requirements regarding internal audit activity, great emphasis is placed on performing engagements in technology and big data by using analytics. The framework defines the methodological requirements regarding analytical procedures of internal auditors when performing assurance engagements.

In Croatia, the legal framework related to internal audit in financial institutions, public sector, and public interest entities relies on the requirements of the International Professional Practices Framework (IPPF). Analytical procedures can play a major role in preventing and detecting irregularities, errors and frauds that result from incorrect disclosure in financial statements, 
which is in the domain of internal controls over financial reporting (Tušek et al., 2014:157). In the context of internal auditing, analytical procedures are efficient tools, techniques and procedures used for comparing, forecasting, analysing and synthesizing available data in order to reach certain conclusions on patterns, anomalies, trends, expected values and to detect unexpected values and fluctuations that direct attention to problem areas and weaknesses of internal control system, business operations, management and other risks that organisations face. Other terms used to refer to analytical procedures are analytics, data analysis, analytical tools, and analytical review. "Analytics is the science of analysis. Analysis is the process of disaggregating information into smaller parts to gain a better understanding of the data." (Soileau, J. et al. 2015: 11) "Changes in technology may make the use of APs more effective and efficient." (Trompeter \& Wright, 2010: 683)

International Standards for the Professional Practice of Internal Auditing in Standard 2320 - Analysis and Evaluation stipulate that "internal auditors must base conclusions and engagement results on appropriate analyses and evaluations." (IIA, 2016) In addition, Standard 2240 - Engagement Work Program explains, "work programs must include the procedures for identifying, analyzing, evaluating, and documenting information during the engagement." (IIA, 2016) The Standards are very broadly set and may include various analysis techniques. In order to explain its meaning more accurately, Implementation Guidance has been developed. Analytical procedures may also be used during engagement planning. "Examples of analytical procedures include: (1) ratio, trend, and regression analysis; (2) reasonableness tests; (3) periodto-period comparisons; (4) forecasts; (5) benchmarking information against similar industries or organizational units; (6) internal auditors may further investigate any significant deviations from expectations to determine the cause and/or reasonableness of the variance (e.g., fraud, error, or a change in conditions)." (The IIA, 2016) "Data analysis as used by internal auditors is the process of identifying, gathering, validating, analyzing, and interpreting various forms of data within an organization to further the purpose and mission of internal auditing. Data analysis is typically used throughout the execution of assessment activities as well as providing other valueadded consulting activities." (The IIA, GTAG, 2011: 3)

The development and increased use of advanced computer assisted tools and techniques (CAATTs) and analytical procedures complements the IIA's standards. Using CAATTs is unimaginable without analytical procedures, and using analytical procedures is significantly facilitated by information technology. In addition, the development of technology enables the development of new analytical techniques and procedures which were non-feasible in the period of manual data processing.

According to the literature, the most commonly used analytical procedures in internal audit engagements are trend analysis, reasonable tests, financial ratios, statistical analytical procedures as simple regression, multiple regression, ARIMA and X-11 models (Wilson \& Colbert, 1991; Lee \& Colbert, 1997; Allen et al., 1999; Koskivaara, 2007; Vunchnich, 2008). In addition to the most commonly used procedures, there are many others which are expected to have a more significant role in the future, such as artificial neural networks (Koskivaara, 2007) or process mining of event logs (Jans et al., 2014). Fraser et al. 
(1997) classified analytical procedures as non-quantitative or more judgmental than simple quantitative, and finally advanced quantitative.

Highlighting the importance of analytics and technology in contemporary development of internal auditing, which is supported by the most used professional framework, it is necessary to emphasize the purpose and role of analytics in auditing environment. In this context, to support research problem and objectives and using previous researches we investigated the possible benefits of using analytical procedures, auditors' skills and knowledge, the degree of use of advance methodology, and the role of technology. The conducted survey is useful for supporting the obtained research results and making conclusions on the state and perspectives of using analytical procedures in assurance engagements in Croatia.

\section{LITERATURE REVIEW}

The development of the internal audit profession includes two main pillars; the first includes the mission, purpose, objective and scope of internal auditing, and the second covers the methodology of carrying out engagement activities. Recent studies on the development of methodology have put in the foreground a combination of interdisciplinary fields such as analytics, technology and big data. Tang et al. (2017) state that the use of data analytics should be a priority for future internal auditing. Advanced analytics are newly introduced to internal auditing, which is supported by Li et al. (2018) who concluded that most companies do not use full audit analytics. Changing from a traditional to contemporary approach of internal auditing usually implies its developmental role by focusing on policies, transactions and compliance to risk-based approach that focuses on goals, strategies and risk management processes (Lindow \& Race, 2002: 29).

The applied methodology of performing internal audit activities can also be considered 'traditional' or 'contemporary'. Caratas \& Spatariu (2014) define methodology as 'traditional' when it includes detailed manuals, annual and five-year plans, and 'contemporary' when it includes principle-based approach and flexibility supported by 'extended' skills involving technology, business models, data mining and analysis. 'Traditional' methods highlight non-analytical auditing techniques such as verification, vouching, confirmations, examination, testing and, in that system, analytical procedures are in the background as an additional tool. 'Contemporary' auditing techniques insist on using analytical procedures proactively, and in line with professional judgement, additionally use nonanalytical techniques to support findings where necessary. "Internal auditors continue to be faced with an expanding scope of activities while resources often remain limited. Across the profession, this has resulted in the increased use of analytics by internal auditors." (Soileau et al., 2015: 10) "Data analytic tools enable auditors to import nearly limitless amounts of data for analysis, which potentially exacerbates information processing limitations." (BrownLiburd et al., 2015: 452)

\subsection{Improving effectiveness and efficiency of internal auditing by using analytics}

The main benefit of using analytics in internal auditing can be summarized as a boost of auditing performance, effectiveness and efficiency (Braun \& Davis, 2003; Bizarro \& Garcia, 2011; Brown-Liburd et al., 2015; Byrnes et al., 2015; Coderre, 
2015; Soileau, J. et al., 2015; Yoon et al., 2015; Cangemi, 2016; Chan \& Kogan, 2016; Richins et al., 2017; Singh, Cheng \& Lai, 2017; Appelbaum et al., 2018; Li et al., Dai, 2018). Singh et al. (2017) stated that using analytics allows a complete revision with a higher level of quality and efficiency while also providing a better insight into business operations.

Chan \& Kogan (2016) concluded that analytical procedures could increase the effectiveness and efficiency of auditing in relation to manual audit procedures. Appelbaum et al. (2018) also stated that analytics prevail over traditional audit procedures. The authors concluded that in certain cases analytical procedures may be more effective and efficient than substantive tests of details, especially in cases when the data set is large and varied. Bizarro \& Garcia (2011) outlined analytical procedures such as summarizing, classifying, cross-tabulating, stratifying, and aging that can be used with software and enhance audit effectiveness and efficiency. On the other hand, Kopotienko (2015) warns that the effectiveness of analytics in internal auditing largely depends on the consistency of the selected analytical procedures and the stage of the audit process.

Li et al., (2018) conducted a study (427 responses) and concluded that increasing efficiency and effectiveness of the audit process will enable auditors to conduct more frequent audits in high-risk areas and increase the reliability of audit results, and increase the probability of finding anomalies. Cangemi (2016) links technology and analytics concluding that new data and mining tools enable easier access to efficient and effective computerized internal auditing techniques. Soileau, J. et al. (2015) emphasize that the use of technology and analytics in auditing opens new approaches to auditing limited only by the auditor's imagination, and that generalized query software can efficiently and effectively 'slice and dice' data.

Li et al. (2018) discussed the importance of technology and audit analytics. The authors concluded that audit analytics requires auditor's special knowledge and skills, which leads to new challenges, and involves the use of advanced statistical techniques or data analytics tools (e.g. data mining) that usually overcomes the potential of typical computer assisted auditing tools and techniques (CAATTs). In addition, the authors emphasize the fact that auditors have limited knowledge so understanding these techniques may be challenging, and can lead to a misuse of the methodology, as well as to a misinterpretation of its results. In addition to increasing efficiency and effectiveness, Soileau, J. et al. (2015) listed additional benefits of using analytics in internal auditing. Those benefits include, but are not limited to, facilitating a reduction in the audit scope by focusing on the higher risk areas, helping to prevent inappropriate inclusion or exclusion, and assisting in obtaining appropriate oversight. In general, it can be concluded that there is a consensus of researchers on increasing effectiveness and efficiency of internal auditing by applying analytical procedures. A significant number of authors relate using analytics to the required technology and necessary level of skills and knowledge.

\subsection{Education, knowledge and skills of internal auditors}

In order to increase the effectiveness and efficiency of internal auditing by using analytics and technology, internal auditors must improve their skills and knowledge. Tang et al. (2017) emphasize that internal auditors need to gain skills and abilities to 
explore the effective uses of data analytics. Braun \& Davis (2003) conclude that additional training is needed and desired by auditors. Byrnes et al. (2015) state that effective application requires learning new skills and specialist support.

The authors agree that appropriate education is essential for more inclusive application of today's opportunities of data analytics in internal auditing (Braun \& Davis, 2003; Brown-Liburd et al., 2015; Byrnes et al., 2015; Coderre, 2015; Yoon et al., 2015; Chan \& Kogan, 2016; Zinca, 2016; Tang et al., 2017; Richins et al., 2017; Li et al., 2018). Curricula at universities must be adapted to new environments and business conditions, emphasizing data analytic skills, understanding and using big data, technology, and all the resulting outcomes such as continuous auditing, blockchain, business intelligence, integrated cloud applications and platform services, cloud-based enterprise resource planning (ERP) systems. Zinca (2016) concluded that contemporary areas of audit interest are cybersecurity, effective risk management, risk model management and data analysis, and mobile applications.

A major challenge and opportunity of internal auditors nowadays is the "use of data or big data volumes analysis, which offer new opportunities for internal auditors in analysing the processes, policies, and systems, increasingly more leveraged during the latest period. On the other hand, the analysis based on large volumes of data, which is very different from a regular audit process requires skills that are scarce for many of the audit function and involves additional costs." (Zinca, 2016: 140-141) Chan \& Kogan (2016) predict that the demand for students with data analytical skills will increase. Appelbaum \& Kogan (2017) point out that companies' systems are integrated with the cloud, the Internet of Things, and external data sources such as the social media. "In educating auditors and accounting students, the curriculum should reflect changing audit evidence sources and ensure more content on advanced data analytics." (Yoon et al., 2015: 436)

The limitations of inadequate knowledge and skills in the application of analytical procedures in internal auditing include the resistance of internal auditors and additional education costs. Tang et al. (2017) in their research found that the internal audit function budget supports internal auditor training so that they acquire the needed skills and abilities to explore the efficient uses of data analytics. Some authors also point that additional specialists in the field of analytics are needed within the internal audit function, while all internal auditors should have a minimum level of expertise in data analytics concepts and tools.

In addition, Coderre (2015) emphasizes that effective analytics require an initial investment of time and a commitment to follow up on results. "Whether Big Data represents a threat or an opportunity to the accounting profession is up to accountants. In order to make sure accountants have a place in the world of Big Data, appropriate education and training need to occur on all levels, from university students through to the continuing education of practicing accountants." (Richins et al., 2017: 76) Data analytics should be considered a required course for all students majoring in accounting and auditing. Coderre (2015) claims that data analytics capabilities of IAFs are consistently below what is desired and that the implementation and improvement of data analytics are the most significant challenges that the typical CAE face. There is no doubt that the future direction of internal auditing methodology development leads to 
an integration of analytics in everyday activities of internal auditors, and the educational system must be prepared to support labour market needs.

\subsection{Information technology and big data in internal auditing}

According to Cangemi (2016), using technology in the audit process has a growing trend, but there is still great room for improvement. "Technological innovations (e.g., electronic commerce, online transactions) have led to a significant increase in the volume and complexity of accounting transactions, making it more challenging for auditors to analyze transactions." (Brown-Liburd et al., 2015: 452)

Conducted studies show that the majority of internal auditors perform their activities using MS Office Excel. Tang et al. (2017) concluded that most internal auditors use spreadsheet software (Excel), while the second most commonly used software is ACL. Another research conducted by Banarescu (2015) confirms that the majority of survey participants use spreadsheet tools such as Microsoft Excel (65\%) or database tools such as MS Access or MS SQL Server (43\%). The results obtained by Wadhawan \& Mahajan (2016) are aligned with the previous ones; $42 \%$ of participants use MS Excel, 36\% of them use ACL, 9\% MS Access, and only 3\% use specialized internal auditing software IDEA.

A lack of traditional software solutions as spreadsheets (MS Office Excel or Access) requires having structured data to perform actions effectively (BrownLiburd et al., 2015: 458). On the other hand, Banarescu (2015) emphasizes the possibility to maximize the benefits offered by the Office package (Excel, Access) or ActiveData for Excel/Office. The future of internal auditing seeks to analyse unstructured large sets of data. "Big data refers to structured or unstructured data sets that are commonly described according to the four $V_{s}$ : Volume, Variety, Velocity, and Veracity." (Gepp et al., 2018: 103) "Data analytic tools used to analyse Big Data give auditors the ability to incorporate and use both structured (e.g., general ledger or transaction data) and unstructured (e.g., email communications, Wi-Fi sensors, electronic tags, freetext fields in databases) data to identify potential transactional anomalies (e.g., unauthorized disbursements), patterns of behavior (e.g., split payments to bypass transaction limit), and trends (e.g., increased fraudulent transactions before a big holiday)." (Brown-Liburd et al., 2015: 454)

"The change in the auditing environment brought by Big Data gives auditors unique opportunities to build up first-mover advantage and achieve economies of scale." (Yoon et al., 2015: 436) "Big data is the product of a technological environment in which almost anything can be recorded, measured, and captured digitally, and thereby turned into data." (Byrnes et al., 2015: 96). Gepp et al. (2018) concluded that auditing would greatly benefit from embracing the use of big data techniques. Richins et al. (2017) stated that the effective leverage of big data opportunities implies not only understanding data analytics, but also an understanding of company's fundamentals and business strategy.

In addition to big data, internal auditors of the future must be ready to deal with the Internet of Things, augmented reality, virtual reality, Blockchain, artificial intelligence, 3D printing, drones, robotics (PwC, 2018:5). The disadvantages of using technology in internal auditing include the fear of internal auditors to be completely 
replaced by technology, initially at high implementation costs and needed time for implementation. Gepp et al. (2018) indicate that the auditing profession has been slow to adopt big data techniques. Richins et al. (2017) argue that technology can push out the need for accountants and auditors by emphasizing the view that business understanding provides auditors with a competitive advantage over data scientists.

Soileau, J. et al. (2015) indicate that the application of analytics without understanding the related business drivers can significantly reduce the efficiency of the tool. Richins et al. (2017) give an example of the need for internal auditors in advanced technology surroundings. "Performing substantive tests on entire populations does not negate the need for auditors. In all cases, the objective remains to generate a list of outliers that will require follow-up by an auditor with good critical thinking skills in order to distinguish between spurious and nonspurious outliers and determine whether financial statements are free from material misstatement." (Richins et al., 2017: 72). The consequence of integrating analytics in internal audit mind-set and using advanced technology to achieve auditing goals will have similar results as computers entering the daily business activities in the last quarter of the $20^{\text {th }}$ century. These trends will enable auditors to accomplish strategic and engagement plans and objectives more efficiently and effectively.

In our opinion, technology will not replace internal auditors. They are necessary in the context of professional judgement, understanding business processes and causative consequences. It is wellknown that internal auditors should be multidisciplinary and think logically. That is their most important advantage and strength. Additionally, "analytics must be systematically incorporated into the audit mind-set and the audit methodology as opposed to ad hoc to be more effective." (Soileau, J. et al., 2015: 10) Chan \& Kogan (2016) conclude that the auditors' main focus will be on expressing professional judgment and technology efficiency allows them to reallocate their time to the evaluation of exceptions or anomalies.

\subsection{Usefulness of analytics in internal auditing}

Researchers emphasize the usefulness of analytics in internal auditing from two perspectives. First, the question is where and how analytics are used in the internal audit process, and second which analytics are used.

According to Soileau et al. (2015), the usefulness of analytics can be observed at the macro and micro level. "At the macro level (resource allocation), analytics assists auditors in determining 'where' to audit; for example, as part of the risk driven audit planning process, analytics is an excellent tool to focus audit efforts and maximize risk assurance and consulting. At the micro level (engagement planning), analytics assists auditors in determining 'what' to audit. An understanding of analytics, data analysis, and query software will be essential for the internal auditor of the future." (Soileau et al., 2015: 12-13).

Numerous authors emphasize the benefits of using analytics in all stages of the auditing process (Soileau, J. et al., 2015; Kopotienko, 2015; Moolman, 2017). Marks (2009) stresses that analytics should be an integral part of audit planning and Glover et al. (2000) indicate that the results of analytical procedures may influence the revision of audit plans. Glover et al. (2000) in their study obtained contradicting results 
regarding the revision of preliminary audit plans in accordance with the conclusion of the analytical procedures where significant unexpected fluctuations were revealed.

"Our results also indicate that a high percent of auditors does not revise audit plans even when faced with large changes in audit risk (revealed by analytical procedures)." (Glover et al., 2000: 43)

Analytical procedures are effective tools for detecting risks and identifying issues in the data (Davuzyan \& Kavut, 2005; Sparks, 2010; Jans et al., 2014; Kopotienko, 2015). Coderre (2015) stresses, "that with data analytics, internal audit can consider not only control weaknesses, but also opportunities to streamline business processes, maximize the organization's use of technology, and focus senior management on the areas of highest risk". Richins et al. (2017) raise awareness of contemporary approaches to internal auditing by which sending out manual confirmations is replaced by blockchain type of technology that enables automatic confirmations. In addition to that, Brown-Liburd et al. (2015) conclude that analytic techniques allow auditors to analyse all client transactions. Sparks (2010) highlights that "data analysis tools allow the auditor to interrogate large volumes of data, and run multiple queries to look for and extract unknown information, which assists in detecting internal control violations, errors and potential fraud" (Sparks, 2010: 14).

Considering the second point of view, which analytics to use, Yoon et al. (2015) offer a wide range of procedures that can be used in the big data era. Those procedures are pattern recognition, data mining, and natural language processing that has improved the predictive power of data analysis routines, sophisticated data-mining techniques, such as visualization, predictive modelling, association, and clustering which are required to analyse big data effectively.

The authors highlight possibilities of big data usefulness. "For example, shipping documents are used to verify shipments, but GPS data provide a more reliable, tamperresistant data source for verification. In traditional auditing, documents are inspected manually to verify business transactions. In the Big Data environment, auditors can use text analysis techniques, such as clustering, to parse and summarize documents automatically." (Dhillon \& Modha, 2001) This approach is more efficient and revealing than manual inspection." (Yoon et al., 2015: 433; according to Dhillon \& Modha, 2001) Vasarhelyi et al. (2015) also indicate the usefulness of relating traditional data with new types and amounts of new data, which create opportunities for additional analytics and for increasing the operational value of data analysis.

Moolman (2017) used the available secondary data to identify analytical procedures typically used by auditors according to the literature. The results of the analysis show that "out of the applicable articles concerning financial analysis methods commonly employed by the auditor, 91 percent focused on ratio and trend analysis." (Moolman, 2017: 174) "It is therefore suggested that the auditor consider supplementing normal analytical procedures with additional procedures, including Du Pont, EVA, Altman's Z-score and Benford's Law. These analytical procedures may flag areas of potential misstatement in the financial statements during the risk assessment process." (Moolman, 2017: 181) "Some popular ways to conduct supervised learning include artificial neural networks, classification and regression trees (decision trees), Random Forests, Naïve Bayes, regularized 
regression, support vector machines, and multivariate adaptive regression splines (MARS).” (Gepp et al., 2018: 104)

Li et al. (2018) conducted a research in which the results show that the most frequently used tool is summarizing (5.00), followed by sampling (4.95) and duplicate detection (4.52), and the least used tools are regression (2.38), clustering (2.46), Benford's Law (2.79), and Exam Sequence (2.88). A possible analytic technique is data envelopment analysis (DEA). Davuzyan \& Kavut (2005) analysed the possibility of expanding information potential associated with the group of companies by using data envelopment analysis (DEA). For research purposes, five internal auditors of the group defined six risk factors, and for every risk factor, the relative importance was determined. The results of the research included conclusions that "both internal and external auditors could partly base their resource allocation decisions on these results. (...) Internal auditors could use the results discussed in the text to better advise top management about the overall situation of each firm comprising the group." (Davuzyan \& Kavut, 2005: 304)

Another possible technique that can be used by internal auditors is process-mining method. Jans et al. (2014) conducted a field study research on the usefulness of process mining method for internal auditors in the procurement process in a leading European bank, which is ranked among the top 25 in the world by asset size. As the first research step, the authors needed to identify the designed procurement process in the bank. "The bank's internal auditors did not find any significant ICFR weaknesses with the procurement process, and judged that its SAPe controls were appropriately set to ensure a strong control environment. By contrast, the process mining analysis identified numerous instances of audit-relevant information that warranted follow-up manual investigation by the internal auditors under SAS 56." (Jans et al., 2014: 1771) Trompeter \& Wright (2010) analysed changes in a type of analytical procedures used by auditors by interviewing 36 practicing auditors. "While auditors tend to use simple APs, the current study also suggests, as noted, that they gather and consider a broader array of industry and company information than in the past, particularly nonfinancial information that is widely available through the internet and databases." (Trompeter \& Wright, 2010: 693)

Wang \& Cuthbertson (2015) stressed out eight issues on audit data analytics that should be researched in the future. Nowadays practice shows that internal and external auditors struggle with the use of data analytics in "their audits for a number of reasons. These reasons include difficulty in acquiring appropriate data, a lack of trained staff, reluctance to invest, not knowing where to start, uncertain benefits and costs of the audit, and concerns about 'false positives'." (Wang \& Cuthbertson, 2015: 155-156) "Recent innovations in analytics, or at least media coverage, including visualization, big data, predictive analytics, and machine learning may give the impression that these advances may remove barriers that have inhibited the use of audit data analytics in the past." (Wang \& Cuthbertson, 2015: 156)

\section{DEVELOPING HYPOTHESES}

Researchers emphasise the importance of analytical procedures for enhancing the effectiveness and efficiency of internal auditors. In addition to that, professional institutions encourage internal auditors to use different types of analytical procedures in 
all phases of their activities, including assurance engagements, ad-hoc engagements and consulting services.

Internal auditors are an integral part of a company's environment that significantly impact the scope of their activities and the possibility to use advanced analytics and technology. If the management of a company does not want or cannot invest in computer-assisted audit tools and techniques (CAATTs), internal auditors do not have an appropriate platform to perform engagements in accordance with the latest recommendations of the Institute of Internal Auditors that, among others, includes auditing big data by using advanced analytics.

Last, but not least, the determinant of using advanced analytics in internal audit engagements is the level of company development measured by the degree of computerization. Enterprise system software (enterprise resource planning - ERP) is the necessary platform for analysing big data, which opens up the potential to use advanced CAATTs and advanced analytical procedures.

As elaborated in the introduction, the research idea underlines the problem of using analytical procedures in assurance engagements of internal auditors in contemporary business conditions in Croatia. The research focuses on the problem of availability of technology to internal auditors to perform their engagements, and in line with that, internal auditors' skills and knowledge to apply a spectrum of different analytics. The research problem is relevant as a requirement for the internal audit function to be efficient and effective in obtaining the results of assurance engagements in a form of applicable recommendations that should have measurable effects. The research problem includes investigation of using analytical procedures in assurance engagements as a leverage of effectiveness and efficiency of internal audit activity. The research tries to give an answer to the question to what extent, measured by the level of analytics application, internal audit functions in Croatia are adapting to those processes. In order to investigate the research problems, we developed several research objectives listed in the introduction, which resulted with the four research hypotheses.

The internal audit activity in Croatia is concentrated in the public-sector entities. Internal auditing in the Croatian public sector is coordinated by the Sector for Harmonization of Internal Audit and Financial Control (Central Harmonization Unit) which is in charge of the preparation of financial management and control, internal auditing methodology, and performance standards. The methodology used emphasizes the need to use analytical procedures in internal auditors' engagements. On the other hand, financial institutions that are also required to establish an internal audit function in Croatia, are predominantly owned by foreign companies, and accordingly use their methodology that is not publicly disclosed.

Nevertheless, internal auditors in Croatia are required to conduct assurance engagements in accordance with the International Professional Practices Framework (IPPF). As it was stated earlier, the Framework in its mandatory guidance assumes using data analytics, and in its recommended guidance encourages the use of advanced technology, big data analysis, and analytics. In accordance with that, the research objective is to investigate if internal auditors in Croatia comply with the International Professional Practices Framework and prescribed methodology for public sector entities regarding the 
use of analytical procedures in assurance engagements. Respecting research objective first research hypothesis includes testing if Croatian internal auditors use analytical procedures in at least one phase of assurance engagements. The results will show whether internal auditors in Croatia respect the required methodology in their activities regarding analytical procedures.

In addition to the need to use analytical procedures in assurance engagements, the International Professional Practices Framework (IPPF), in their implementation guidance, encourages internal auditors to use them in all audit stages. The Global Data Technology Audit Guide (GTAG) states that analytical procedures can be used in various stages of internal audit engagements (The IIA, GTAG, 2011: 5). In the planning stage, it can be used as an effective detector of data-driven indicators of risk or emerging risk in an organization. Internal auditors in their plans must focus on the areas of the highest concern. During the preparation stage, internal auditors "can source the data required for the audit engagement, do data integrity and validity checks, and prepare test routines for staff auditors to use once the audit commences" (The IIA, GTAG, 2011: 5-6). Performing internal audit engagements using advanced analytical procedures is narrowly related to technology. Protiviti's research emphasizes the advantages of using analytics in different phases of assurance engagements. The most significant advantages in planning are ability to risk profiling, test data simulation and statistical sampling; in performing engagements the advantages are continuous controls monitoring, fraud indicators, predictive risk identification and control simulation; and in reporting the advantages are risk quantification, real-time exception management and root cause investigation (Protiviti, 2018:25).
Profession's developing perspective is to move from testing samples of data to analysing the entire data population. Sampling or spot check "may be ineffective at uncovering anomalies and indicators of failed or inefficient internal controls" (The IIA, GTAG, 2011: 5-6). Respecting the implementation guidance of the Institute of Internal Auditors, an important research objective includes revealing the level to which analytical procedures are integrated in the assurance engagements in Croatia. Are analytical procedures used only to comply with the form or do they represent a useful, integrated tool for internal auditors to gather audit evidence and make conclusions on the organization's operations, effectiveness of risk management, controls, and governance processes? In that context, it can be concluded that more advanced function uses analytics in the reporting and followup phase, and the least developed ones uses them only in the planning phase.

As it was shown earlier, the Framework especially emphases the usefulness of analytics as a tool for planning and performing engagements, and its usefulness in reporting and follow-up is placed in the background. The research objective is to make conclusions on the level of using analytical procedures in four typical phases of assurance engagements - planning, performing, reporting, and follow-up. The results will show the advancement of the conducted assurance engagements by giving insights on the readiness of internal auditors to use analytics in all phases, and more important, the results will be informative for making an impression about the auditing approach of respondents in conducting their activities.

It can be concluded that if internal auditors are not using analytical procedures in a particular phase, they are only using non-analytical auditing procedures. 
The results may suggest internal auditors' lack of knowledge and skills regarding the usefulness of analytical procedures in different phases of assurance engagements. Respecting the research objective, the second research hypothesis includes testing the statement that analytical procedures are not applied equally in different phases of the internal audit assurance engagements.

Another research dimension is aimed at the advancement level of using analytical procedures. It is not only important to use analytical procedures, but the important question is which analytical procedures are used by internal auditors in assurance engagements. In the first part of the paper, we elaborated on the different types of analytical procedures that internal auditors are encouraged to use in their activities. Those procedures include very simple ones, such as differences between the two values, and very complexed ones such as neural networks.

The higher level of using complex procedures can be related to the higher advancement level of the internal audit function. It is important to emphasize that the level of using complex analytical procedures and big data analysis depends on three factors: knowledge and skills of internal auditors, the availability of CAATTs, and the company's level of development regarding the ERP systems. The first two factors are directly related to the analytical procedure application, and the availability of CAATTs and company's development are directly related to the possibility of implementing continuous auditing, which goes beyond the scope of this paper.

The statement about technology availability is directly tested with respondents. Out of 155 internal auditors included in the research, 57 of them $(37 \%)$ answered that they have not implemented any computer-assisted tool, and 98 of them $(63 \%)$ declared that the department has at its disposal some kind of technology. The research objective involves investigating the advancement of internal audit function in Croatia measured by the complexity of used analytical procedures by internal auditors in order to be able to evaluate internal auditors' skills and knowledge. Adequately used analytical procedures are considered efficient and reliable techniques for obtaining audit evidence.

The main premise is that skilled internal auditors with an adequate level of knowledge, and available information technology, will use more complex analytical procedures in order to save financial and human resources. Previously obtained results show that the majority of internal auditors uses analytical procedures in at least one phase of assurance engagements, but the question is which procedures they use. To make a conclusion on the level of development of internal auditing in Croatia it is necessary to investigate the diversity of analytics used. In line with that, the third research hypothesis includes the premise that different groups of analytical procedures are not used equally in the internal auditors' assurance engagements.

Taking previously obtained results into account it is expected that the degree of using different analytical procedures is determined by the knowledge and skills of internal auditors. By that, internal auditors can be divided into two main groups, the skilled internal auditors with a higher level of knowledge who will more often use nontraditional and advanced analytics - 'contemporary internal auditors', and the ones who will be prone to using simpler analytical procedures and focus on other non-analytic audit procedures - 'traditional internal auditors'. The objective of the research is 
to investigate whether internal auditor in Croatia are 'traditional' or 'contemporary' as measured by the diversity and complexity of used analytical procedures in their engagements. In order to investigate the given objective, the fourth research hypothesis is designed: the simple and complex analytical procedures are not applied equally by internal auditors in Croatia.

\section{RESEARCH SAMPLE AND METHODOLOGY}

The problem of using analytical procedures in assurance engagements of internal auditors in contemporary business conditions in Croatia is investigated by survey method. The survey was carried out in the period from October 2017 to December 2017. The questionnaire included questions related to the application of analytical procedures in collecting and processing data, and types of analytical tools and procedures used in different phases of internal audit engagements. All questions were closed type ones where the respondents could choose one or several suggested answers. The data were analysed using appropriate descriptive and inferential statistics.

The population covered by the research includes entities required to establish an internal audit function in accordance with Croatian regulations. Internal auditing in Croatia is regulated mainly for public sector entities. The public sector of every country represents a complex system of various fiscal, legislative, and executive entities focused on achieving welfare and prosperity. The Government in Croatia covers central, regional and local government (Bejaković et al., 2011: 107). The other component of the public sector are public corporations. The International Monetary Fund defines public corporations as "all resident corporations controlled by government units or by other public corporations" (IMF, 2014: 27). In Croatia, the definition of public corporations can be extended to 'controlled or owned' by government units (Kesner-Škreb, 1993: 91). According to the Government Finance Statistics Manual 2014, public corporations can be non-financial or financial corporations, "depending on the nature of their primary activity" (IMF, 2014: 30). Other corporations that are not owned or controlled by the government represent private sector entities. The private sector includes private entities, quoted companies, and financial institutions. According to the Consolidated Annual Report on Internal Control System in the Public Sector in Croatia for 2016 there was a total of 103 budget users obliged to establish the internal audit function (Ministry of Finance, 2017: 35), and by today they all have established this function. In addition, there was a total of 10 state bodies and 3 health institutes at local level that were not obliged to establish an internal audit function but have it established. According to the reported data, it can be concluded that 113 internal audit establishments operate in the general government component of the public sector in Croatia.

Regarding public corporations, the Ministry of Finance disclosed annual financial statements for 55 corporations in 2016 out of which 8 were financial public corporations and 47 of were are non-financial public corporations (Ministry of Finance, 2017, webpage). At the end of 2017, there were 22 active banks in Croatia (The Croatian Financial Services Supervisory Agency, Register of credit institutions, 2017).

Based on the conducted research, it can be concluded that in Croatia 265 entities that are obliged to establish an internal 
audit function in their organization structure operate (Table 1). The majority of entities that have established the internal auditing come from the Government (41.09\%), followed by the private sector (mostly financial institutions). In addition, it is important to respect the fact that there are companies that are not obliged, but have nonetheless established the function. It is not possible to determine the number of those companies, considering that they are not liable to disclose that information publicly.

Table 1: Total number of entities obliged to establish internal audit function in Croatia

\begin{tabular}{|l|c|c|c|}
\hline \multicolumn{1}{|c|}{ Type } & Obliged & Established & $\begin{array}{c}\text { Established } \\
\text { (as a \%) }\end{array}$ \\
\hline $\begin{array}{l}\text { General } \\
\text { government }\end{array}$ & 103 & 113 & $41.09 \%$ \\
\hline $\begin{array}{l}\text { Public } \\
\text { corporations }\end{array}$ & 55 & 55 & $20.00 \%$ \\
\hline Private sector & 107 & 107 & $38.91 \%$ \\
\hline Total & 265 & $\mathbf{2 7 5}$ & $100.00 \%$ \\
\hline
\end{tabular}

Source: Prepared by authors referring to previously explained data

The invitation to participate in the research was sent to almost all obliged entities, and several ones within the nonobliged private sector in Croatia. The questionnaire was sent via e-mail to 302 internal auditors and 50 were undeliverable. Out of the total sent invitations, 155 respondents completed the survey and 112 partially responded to the questions. The conducted analysis covers only completed questionnaires which make a response rate of $61.51 \%$, resulting in the error of margin of $4.86 \%$, and confidence level of $95.14 \%$ (for research purposes, we will round it to the significance level of $5 \%$ and confidence level of $95 \%$ ).
The research sample includes responses from internal auditors employed within diverse economic activities. The majority of respondents are employed in the general government sector, which includes cities, counties, extra-budgetary users, health institutions, mandatory pension companies, ministries, state offices, universities, and other state entities $(84 ; 54.19 \%)$. The Government, along with financial services entities, represents the bulk of entities that must establish the internal audit function in Croatia.

In the Government component of the public sector in Croatia, there are 113 internal audit units. The number represents the total number of obliged entities within the Government sector, which leads us to the fact that the research sample covers $74.34 \%$ of the population.

The second component of the Croatian public sector are public corporations that include financial public corporations and non-financial public corporations. In general, entities that provide financial services are obliged to establish the internal audit function. For research purposes of this analysis, corporations from the public sector will be observed together with other privately-owned financial services entities. Altogether, public corporations, as a part of the public sector in Croatia, comprise only non-financial public corporations. There is a total of 47 public corporations in Croatia, and the research sample includes 27 entities from the construction, distributive trades, industry and non-financial services which makes $57.45 \%$ of the population.

In total, 107 private entities are obliged to establish an internal audit function in Croatia. Private entities are represented by credit institutions (banks), AIF management companies, mandatory and voluntary pension companies, insurance and reinsurance 
companies, leasing, and factoring companies. The research sample includes 36 entities from that sector which makes 33.64\% of the population. Inevitable and extremely significant entities from that sector are credit institutions (banks). In 2017, Croatia had 22 active banks. The research sample includes 15 banks which covers $68.18 \%$ of the population.

Private entities represent companies that are not obliged to establish the internal audit function but have established it. The sample includes 8 companies, mostly service providers, such as telecommunication or hotels, and retailers. It is not possible to determine the population of those companies. Overall, it can be concluded that the sample covers a representative distribution and number of entities. There are 267 entities in Croatia that are obliged, and have established internal audit function, and the sample covers 147 entities which makes $55.06 \%$ of the population. In addition to the obliged entities, the conducted analysis includes 8 entities that established the internal audit function voluntarily.

Table 2: Sector classification of the entities included in the research

\begin{tabular}{|l|c|c|}
\hline SECTOR & $\mathbf{n}$ & $\mathbf{\%}$ \\
\hline $\begin{array}{l}\text { Private } \\
\text { sector }\end{array}$ & 48 & 31.0 \\
\hline $\begin{array}{l}\text { Public } \\
\text { sector }\end{array}$ & 107 & 69.0 \\
\hline Total & $\mathbf{1 5 5}$ & $\mathbf{1 0 0 . 0}$ \\
\hline
\end{tabular}

Source: Ježovita, A., Tušek, B., Žager, L. "Application of analytical procedures in internal auditing”, Survey, Online Questionnaire: 17/1027/12 2017

Out of the total number of respondents, $48(31 \%)$ of internal auditors are employed in the private sector, and 107 $(69 \%)$ are from the public sector (Table 2). As it was noted earlier, apart from private non-financial corporations, private sector includes obliged financial services entities. The sample distribution is adequate and can be compared to the population.

Observed by the economic activity of entities included in the sample, it can be concluded that the majority internal auditors are employed in public services at the state and local level $(38 \%)$ or in financial services $(26 \%)$.

Table 3: The size of the entities included in the research by the total number of employees

\begin{tabular}{|l|r|r|}
\hline \multicolumn{1}{|c|}{$\begin{array}{c}\text { NUMBER OF } \\
\text { EMPLOYEES }\end{array}$} & \multicolumn{1}{c|}{$\mathbf{n}$} & \multicolumn{1}{c|}{$\%$} \\
\hline$<50$ & 18 & 11.6 \\
$50-200$ & 49 & 31.6 \\
$201-500$ & 32 & 20.6 \\
$>500$ & 56 & 36.1 \\
Total & $\mathbf{1 5 5}$ & $\mathbf{1 0 0 . 0}$ \\
\hline
\end{tabular}

Source: Ježovita, A., Tušek, B., Žager, L.

"Application of analytical procedures in internal auditing”, Survey, Online Questionnaire: 17/1027/12 2017

Observed by the number of employees in the analysed entities, more than half of internal auditors are employed within entities with more than 200 employees (Table $3)$. It is interesting to notice that $36 \%$ of analysed entities have more than 500 employees. Those are complex systems with a layered organizational and managerial structure. It is common for such entities to have established an internal audit function regardless of the legal obligation. Croatian legislation on the establishment of the internal audit function in the public sector emphasizes the criterion of at least 50 employees (extra-budgetary users, towns of county headquarters, and other legal entities in the public sector) (Rulebook on Internal Audit in Public Sector, Official Gazette Number 
42/2016, Article 3). Nevertheless, our sample includes 18 entities (11.6\%) with an established internal audit function that have less than 50 employees. Most of those entities are financial institutions, including mandatory pension companies, leasing and factoring companies.

Table 4: The size of internal audit departments included in the research by the number of employed internal auditors

\begin{tabular}{|l|r|r|}
\hline \multicolumn{1}{|c|}{$\begin{array}{c}\text { SIZE OF THE INTERNAL } \\
\text { AUDIT FUNCTION }\end{array}$} & \multicolumn{1}{c|}{ n } & \multicolumn{1}{c|}{$\%$} \\
\hline $1-2$ & 108 & 69.7 \\
$3-5$ & 30 & 19.4 \\
$6-10$ & 11 & 7.1 \\
$>10$ & 6 & 3.9 \\
Total & $\mathbf{1 5 5}$ & $\mathbf{1 0 0 . 0}$ \\
\hline
\end{tabular}

Source: Ježovita, A., Tušek, B., Žager, L.

"Application of analytical procedures in internal auditing”, Survey, Online Questionnaire: 17/1027/12 2017

The conducted research focuses on internal audit function as a test variable. Considering that, the size of the department measured by the number of internal auditors employed represents an important determinant (Table 4). The largest proportion in the sample has small internal audit units, employing one or two internal auditors $(69.7 \%) .{ }^{1}$ The sample includes only six entities in which internal audit function has more than 10 employees. A significant proportion in the sample has medium-sized internal audit departments that employ between 3 and 5 internal auditors (19.4\%).
Table 5: The position of internal auditors included in the research within the department

\begin{tabular}{|l|r|r|}
\hline POSITION & \multicolumn{1}{|c|}{ n } & \multicolumn{1}{c|}{$\%$} \\
\hline Chief Audit Executive (CAE) & 85 & 54.8 \\
Senior Internal Auditor (SIA) & 12 & 7.7 \\
Internal Auditor (IA) & 46 & 29.7 \\
Other & 12 & 7.7 \\
Total & $\mathbf{1 5 5}$ & $\mathbf{1 0 0 . 0}$ \\
\hline
\end{tabular}

Source: Ježovita, A., Tušek, B., Žager, L.

"Application of analytical procedures in internal auditing”, Survey, Online Questionnaire: 17/1027/12 2017

The Chief Audit Executive (CAE) can be considered the most competent representative of the overall internal audit activity because it can be expected that he is included in all the processes and engagements of the function at every level, operational and performance ones. More than half of the respondents are Chief Audit Executives (54.8\%), and $7.7 \%$ of the respondents declared themselves as Senior Internal Auditors and they can be considered auditors with a greater extent of authorizations and responsibilities than internal auditors (Table 5). The result is expected considering that the majority of respondents is employed in small internal audit departments.

\section{RESULTS AND DISCUSSION}

The following part of the questionnaire focuses on the phases of the internal audit process (assurance engagements) in which the respondents participate and define the types of analytical procedures that they use in those phases. This part represents the backbone of the conducted research.

1 The Institute of Internal Auditors in April 2011 published Supplemental Guidance (previously known as Practice Guide) where small internal audit function is defined as the one that meets one or more of the following criteria: (a) one to five auditors; (b) productive internal audit hours below 7,500 a year; (c) limited level of co-sourcing or out-sourcing (The IIA, 2011: 3) 
Management, Vol. 23, 2018, No.2, pp. 15-46

A. Ježovita, B. Tušek, L. Žager: THE STATE OF ANALYTICAL PROCEDURES IN THE...

Table 6: Participation of internal auditors in different phases of assurance engagements

\begin{tabular}{|c|c|c|c|c|c|}
\hline \multirow{2}{*}{$\begin{array}{l}\text { In your work, you participate in the following } \\
\text { phases of the internal audit process (the } \\
\text { assurance engagements): }\end{array}$} & \multicolumn{2}{|c|}{ Yes } & \multicolumn{2}{|c|}{ No } & \multirow{2}{*}{ Total } \\
\hline & $\mathbf{n}$ & $\%$ & $\mathbf{n}$ & $\%$ & \\
\hline Internal Audit Planning & 143 & $92.3 \%$ & 12 & $7.7 \%$ & 155 \\
\hline Performance Phase & 135 & $87.1 \%$ & 20 & $12.9 \%$ & 155 \\
\hline Reporting & 137 & $88.4 \%$ & 18 & $11.6 \%$ & 155 \\
\hline Follow-up & 140 & $90.3 \%$ & 15 & $9.7 \%$ & 155 \\
\hline
\end{tabular}

Source: Authors' calculation by using Ježovita, A., Tušek, B., Žager, L. "Application of analytical procedures in internal auditing”, Survey, Online Questionnaire: 17/10-27/12 2017

The largest share of respondents is included in the planning phase of the engagements (Table 6). This is not unusual and unexpected considering the fact that it is often emphasized that the planning represents the most important phase, and that the plan must be flexible. Considering the fact that over $60 \%$ of respondents declared that they are chief audit executives or senior internal auditors it is expected that the largest proportion of respondents is included in all phases of the engagements, and especially in planning, reporting and follow-up. The results can be interpreted regarding the size of the internal audit function, where $70 \%$ of the departments employ one or two auditors, and an additional 20\% employ 3-5 auditors. This leads us to the conclusion that all internal auditors must be involved in all operational and auditing activities of the department, including all phases of the assurance engagements, which is consistent with the obtained results.

Observing by phases, the level of using analytical procedures in assurance engagements differs. To test the statistical significance of those differences, one-sample Chi-Square test is used. The results show that the null hypothesis, i.e. that the level of using analytical procedures in planning and performing occur with equal probabilities (p-value 0.000 ), should be rejected. On the other hand, the level of using analytical procedures in reporting (.377) and follow-up (.574) phases occurs with equal probability, i.e. half of internal auditors are using analytical procedures, and another half are not.

Respecting the results for planning and performing assurance engagements, where internal auditors use analytical procedures significantly more $(72.9 \%$ and $86.5 \%)$ as

Table 7: Using analytical procedures in different phases of the assurance engagement

\begin{tabular}{|l|c|c|c|c|c|c|c|}
\hline \multirow{2}{*}{$\begin{array}{c}\text { Using analytical } \\
\text { procedures in the } \\
\text { particular phase of the } \\
\text { assurance engagement: }\end{array}$} & \multicolumn{2}{|c|}{ Yes } & \multicolumn{2}{c|}{ No } & \multicolumn{2}{c|}{ One-Sample Chi Square Test } \\
\cline { 2 - 7 } \cline { 5 - 8 } & $\mathrm{n}$ & $\%$ & $\mathrm{n}$ & $\%$ & & $\begin{array}{c}\text { Significance } \\
\text { level }\end{array}$ & $\begin{array}{c}\text { Decision about the } \\
\text { null hypothesis }\end{array}$ \\
\hline Internal Audit Planning & 113 & $72.9 \%$ & 42 & $27.1 \%$ & 155 & .000 & Reject \\
\hline Performance Phase & 134 & $86.5 \%$ & 21 & $13.5 \%$ & 155 & .000 & Reject \\
\hline Reporting & 83 & $53.5 \%$ & 72 & $46.5 \%$ & 155 & .377 & Accept \\
\hline Follow-up & 81 & $52.3 \%$ & 74 & $47.7 \%$ & 155 & .574 & Accept \\
\hline
\end{tabular}

Source: Authors' calculation by using Ježovita, A., Tušek, B., Žager, L. "Application of analytical procedures in internal auditing”, Survey, Online Questionnaire: 17/10-27/12 2017 
compared to the number of those that do not use them $(27.1 \%$ and $13.5 \%)$, the first research hypothesis (H1) can be accepted. Internal auditors in Croatia use analytical procedures in at least one phase of assurance engagements (Table 7).

The fact that internal auditors in Croatia use analytical procedures in at least one phase of assurance engagements leads us to the conclusion that they respect the guidance in this regard. Taking into account the direction of internal auditing development on the global scale, the obtained results show that internal auditing in Croatia is keeping track with other countries. Protiviti's (2018) results show that 76\% of internal audit departments in the AsiaPacific area, $76 \%$ in Europe and $63 \%$ in North America use data analytics as part of the audit process (Protiviti, 2018:3). In addition, our research shows that more than $60 \%$ of respondents have at their disposal certain software and that at the global level the majority of internal auditors uses spreadsheets such as MS Excel to process data (Tang et al., 2017; Banarescu, 2015; Wadhawan \& Mahajan, 2016). It can be concluded that the state of internal auditing in Croatia is aligned with the global advancement of the profession.

A simple way to observe and make conclusions about applying analytical procedures equally in all phases is to observe the response frequencies. We have previously concluded that internal auditors in Croatia use analytical procedures in assurance engagements, and that it is particularly emphasized in the planning and performing phases. We can notice that $86.5 \%$ of internal auditors use analytical procedures in performing assurance engagements, compared with the follow-up where $52.3 \%$ of respondents use them. There are obvious differences in the use of analytical procedures in relation to the phases of assurance engagements. To make certain conclusions about the statement that analytical procedures are not applied equally in different phases of the assurance engagements, non-parametric independent samples Kruskal-Wallis Test was used (Table 8). The null hypothesis of the test is that the distribution of mean ranks of using analytical procedures is the same across the different phases of assurance engagements. At the significance level of $5 \%$ empirical ChiSquare is 56,057 with 3 degrees of freedom and an empirical p-value of 0.000 . Because the empirical p-value of 0.000 is below the theoretical significance level of 0.05 the null hypothesis should be rejected. By rejecting the statistical null hypothesis, we are accepting our research hypothesis which leads us to the conclusion that analytical procedures are not applied equally in different phases of the internal audit assurance engagements.

Table 8: Results of the Kruskal-Wallis test

\begin{tabular}{|c|c|}
\hline Test Statistics & Using \\
\hline Chi-Square & 56.057 \\
\hline df & 3 \\
\hline Asymp. Significance & 0.000 \\
\hline \multicolumn{2}{|l|}{ a Kruskal Wallis Test } \\
\hline b Grouping Variable: & \\
\hline
\end{tabular}

Source: Authors' calculation by using Ježovita, A., Tušek, B., Žager, L. "Application of analytical procedures in internal auditing”, Survey, Online Questionnaire: 17/10-27/12 2017

The obtained results that there is a statistically significant difference in using analytical procedures in different phases of assurance engagements, leaves space for internal auditors to improve their analytical methodology, especially in reporting and follow-up phases where slightly over $50 \%$ of respondents use analytical procedures. 
Encouraging is the result that almost $90 \%$ of internal auditors in performing assurance engagements and over $70 \%$ in planning use analytical procedures. Discouraging is the result that there is a significant difference in the level of using in the first stages compared to the last stages of assurance engagements, which leads us to the conclusion that analytical procedures are only partly integrated in the activities of internal auditors and that internal audit departments in Croatia may be considered moderately developed. The results obtained by Protiviti (2018) show lesser dispersion in using analytics between phases. According to the Protiviti's results, $63 \%$ of internal audit functions use analytics in planning, $65 \%$ in performing engagements, $42 \%$ in reporting and 39\% in follow-up (Protiviti, 2018: 12). The obtained results may serve as an attention alert for the education system, regulators, and to scientists as a genesis for more profound investigation of the reasons why analytical procedures are not used equally in all phases of assurance engagements. A significant conclusion is related to the fact that Croatian internal auditors have indicated a higher proportion of using analytics in all phases. Regarding that, we can address the question on the perception on analytics by internal auditors in Croatia on the one hand, and internal auditors from more developed countries with access to contemporary technology on the other. In order to test that, we interviewed internal auditors to determine which analytics they use.

Following set of questions in the survey is related to the type of analytical procedures that internal auditors use in different phases of assurance engagements. The obtained answers can be related to the level of internal auditors' knowledge and understanding the procedures, and not only their availability in the appropriate CAATTs system. Taking into account

Table 9: Analytical procedures groups and their complexity

\begin{tabular}{|c|c|c|}
\hline Code & ANALYTICAL PROCEDURES GROUPS & $\begin{array}{l}\text { COMPLEXITY DEGREE OF } \\
\text { ANALYTICAL PROCEDURES }\end{array}$ \\
\hline G_1 & $\begin{array}{l}\text { Analysis of fluctuations / deviations, trends, comparison with } \\
\text { industry outcomes }\end{array}$ & VERY SIMPLE \\
\hline G_2 & $\begin{array}{l}\text { Descriptive statistics calculation (e.g., average values, standard } \\
\text { deviations, minimum and maximum values) to identify unusual } \\
\text { transactions. }\end{array}$ & SIMPLE \\
\hline G_3 & $\begin{array}{l}\text { Data analysis by using individual financial ratios such as } \\
\text { liquidity, indebtedness, activity, cost-effectiveness, probability } \\
\text { and/or investment ratios. }\end{array}$ & SIMPLE \\
\hline G_4 & $\begin{array}{l}\text { Analysis using synthetic financial indicators such as Altman's } \\
\text { z-score. }\end{array}$ & MODERATE \\
\hline G_5 & $\begin{array}{l}\text { Advanced statistical procedures such as simple or multiple } \\
\text { regression analysis, ARIMA models, X-11 models, neural } \\
\text { networks. }\end{array}$ & COMPLEX \\
\hline G_6 & Benford's law, data mining, data scanning. & COMPLEX \\
\hline G_7 & $\begin{array}{l}\text { Classification and stratification of data with the goal of finding } \\
\text { patterns and relationship between groups of data elements and } \\
\text { identifying unusual values / names or inappropriate matching. }\end{array}$ & SIMPLE \\
\hline G_8 & $\begin{array}{l}\text { Identification of missing numbers, duplication, and validation of } \\
\text { the date of entry (for example, payments, payroll, receivables, } \\
\text { travel orders, etc.). }\end{array}$ & SIMPLE \\
\hline
\end{tabular}


the existing literature and detecting analytical procedures that are most frequently mentioned in relevant scientific papers, and referring to supplemental guidance Global Technology Audit Guide (GTAG): Data Analysis Technologies (August 2011) of the International Professional Practices Framework (IPPF), chosen analytical procedures are classified into eight groups. The procedures are classified respecting their similarity and complexity (from very simple to complex ones). Contemporary business conditions bring in the focus internal auditors' skills to explain and put into context the results obtained by diverse analytical procedures, and the availability of information technology as a prerequisite to use more complex and advanced analytical procedures (Table 9). It is not the question 'How to obtain the results?' but rather 'What do the results mean?'.

The majority of internal auditors (148 or $95.48 \%$ ) who completed the survey (155) answered the questions related to the application of various analytical procedures in the internal audit assurance engagements. Seven of them skipped this section. We used the Kruskal-Wallis test to investigate the overall differences between the mean ranks of using analytical procedures in different phases of assurance engagements (Table 10).

Table 10: Results of Kruskal-Wallis test

\begin{tabular}{|l|rr|}
\hline \multicolumn{1}{|c|}{ Test Statistics } & \multicolumn{2}{c|}{ Using_AP } \\
\hline Chi-Square & \multicolumn{2}{r|}{359.032} \\
\hline df & & 7 \\
\hline Asymp. Sig. & 0.000 \\
\multicolumn{2}{l}{ a Kruskal Wallis Test }
\end{tabular}

Source: Authors' calculation using Ježovita, A., Tušek, B., Žager, L. "Application of analytical procedures in internal auditing”, Survey, Online Questionnaire: 17/10-27/12 2017
The result of the test shows the empirical value of Chi-Square 359,032 and the significance level of 0.000 with 7 degrees of freedom which means that there are statistically significant differences in the mean ranks of using various analytical procedures in different phases of assurance engagements. Considering all the results, the third research hypothesis that different groups of analytical procedures are not used equally in the internal auditors' assurance engagements can be accepted.

The obtained results confirm that different types of analytical procedures are not equally used by internal auditors in Croatia. The analysis of frequency shows that the most used procedures are simple ones (analysis of fluctuation, deviation, trends, comparison with industry outcomes, financial ratios, classification, identification of missing numbers), and the least used analytics are complex ones (synthetic financial indicators, multiple regression, ARIMA models, X-11 models, neural networks). According to the results, it can be concluded that internal auditors in Croatia are poorly developed regarding technology and knowledge to use more complex analytical procedures. Findings can contribute to the study of the effectiveness of internal audit functions in Croatia where we can conclude that there is a significant room for improvement in order to increase the quality of assurance engagement results. Future results may be directed to investigating other techniques used by internal auditors and specifics of their operations to obtain audit evidence, findings and recommendations in order to detect critical areas and weaknesses of the methodology used.

Later results throw a new light to the previously presented ones regarding the level of use of analytics. Although the level of use of analytics in Croatia is ahead 
of the global state, the fact is that Croatian internal auditors are focused on the simplest analytics. The last part of the paper includes testing the level of using the analytical procedure by complexity. Groups of analytical procedures are classified according their complexity level into two categories "Simple" and "Complex". The "simple" group includes average level of use of very simple (G_1) and simple (G_2, G_3, G_7, G_8) groups of analytical procedures. The "complex" group includes the average level of use of moderate $\left(\mathrm{G}_{-} 4\right)$ and complex (G_5, G_6) groups of analytical procedures. The results are two continuous variables ranging from 0 to 1 .

Table 11: Descriptive statistics for groups of simple and complex analytical procedures

\begin{tabular}{|c|c|c|c|c|c|}
\hline & $\begin{array}{l}\sum_{\bar{\Sigma}}^{\tilde{E}} \\
\end{array}$ & 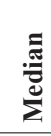 & $\frac{\mathscr{2}}{2}$ & 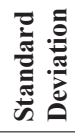 & 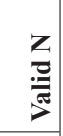 \\
\hline SIMPLE_Yes_avg & .73 & .80 & 1.00 & .28 & 148 \\
\hline COMPLEX_Yes_avg & .22 & .00 & .00 & .29 & 148 \\
\hline
\end{tabular}

Source: Authors' calculation using Ježovita, A., Tušek, B., Žager, L. "Application of analytical procedures in internal auditing”, Survey, Online Questionnaire: 17/10-27/12 2017

The obtained results show that $73 \%$ of 148 internal auditors are using simple analytical procedures, and only $22 \%$ of them are using complex analytical procedures (Table 11). Considering the fact that variables are not normally distributed (the significance level of the Kolmogorov-Smirnov test is 0.000 and the Shapiro-Wilk test 0.000 ) it is better to use median value for evaluation, and nonparametric test for testing the significance of differences.

The difference in using simple and complex analytical procedures is tested by nonparametric Mann-Whitney U Test (Table 12). The null hypothesis of the test assumes that the distributions of simple and complex analytical procedures are the same. Empirical significance level of conduct testing is 0.000 , and is lower than the theoretical significance level of 0.05 , which means that the null hypothesis should be rejected.

Table 12: Ranks of the Mann-Whitney U Test for the complexity level of using analytical procedures

\begin{tabular}{|l|r|r|l|}
\hline $\begin{array}{c}\text { Complexity } \\
\text { level }\end{array}$ & \multicolumn{1}{|c|}{ N } & \multicolumn{1}{c|}{$\begin{array}{c}\text { Mean } \\
\text { Rank }\end{array}$} & \multicolumn{1}{c|}{$\begin{array}{c}\text { Sum of } \\
\text { Ranks }\end{array}$} \\
\hline Simple & 148 & 92.00 & 13616.00 \\
\hline Complex & 148 & 205.00 & 30340.00 \\
\hline Total & 296 & & \\
\hline
\end{tabular}

Source: Authors' calculation using Ježovita, A., Tušek, B., Žager. L. "Application of analytical procedures in internal auditing”, Survey, Online Questionnaire: 17/10-27/12 2017

Based on the obtained results it can be concluded that distributions of the level of use of simple and complex analytical procedures are not the same, i.e. it can be accepted that those distributions are statistically significantly different.

Table 13: Results of the Mann-Whitney U Test for the complexity level of using analytical procedures

\begin{tabular}{|l|c|}
\hline \multicolumn{1}{|c|}{ Test Statistics } & Complexity level \\
\hline Mann-Whitney U & 2.590 .000 \\
\hline Wilcoxon W & 13.616 .000 \\
\hline Z & -11.604 \\
\hline Asymp. Sig. (2-tailed) & 0.000 \\
\hline \multicolumn{2}{|l}{ Grouping Variable: Complexity }
\end{tabular}

Source: Authors' calculation using Ježovita, A., Tušek, B., Žager, L. "Application of analytical procedures in internal auditing”, Survey,

Online Questionnaire: 17/10-27/12 2017

The fourth research hypothesis that the simple and complex analytical procedures are not applied equally by internal auditors 
in Croatia can be accepted (Table 13). The results of the conducted research show that internal auditors are prone to use simple analytical procedures. The most used groups of analytical procedures cover different identification and validation methods (93.2\%), followed by the analysis by using individual financial ratios such as liquidity, indebtedness, activity, cost-effectiveness, probability, and/or investment ratios $(71.6 \%)$. On the other hand, the least used groups of analytical procedures include the most complex ones. Only $9.5 \%$ of respondents use advanced statistical procedures such as simple or multiple regression analysis, ARIMA models, X-11 models, neural networks.

By accepting the fourth hypothesis, we can conclude that in Croatia prevail 'traditional internal auditors' who are using, simple analytical procedures, predominately in planning and performing phases of assurance engagements. The obtained results suggest a need for further education of internal auditors in the fields of information technology, methodology and practice of analytical procedure application. The future objective of the internal audit profession in Croatia should be shifting from 'traditional' to 'contemporary' internal auditors.

\section{CONCLUSION}

The contemporary internal auditing activity is aimed at a new paradigm focused on risk assessment, management adequacy, effectiveness of internal control system, and efficient corporate governance. To increase their effectiveness in increasingly complex, chaotic and accelerating company's environment, internal auditors are compelled to adapt. A significant opportunity regarding adaptation is provided by information technology advancements.
As internal auditing and IT become inseparable, the usefulness of various analytical procedures becomes more important. The level of using IT technology and the level of using analytics complement each other. Using IT is unimaginable without analytical procedures, and using analytical procedures is significantly facilitated by information technology. Taking that into account, we conducted a research survey on the application of analytical procedures by internal auditors in Croatia.

The conducted research confirms that Croatian internal auditors use analytical procedures in assurance engagements. In addition, we found that used analytical procedures are not applied equally in different phases of the internal audit assurance engagements (planning, performing, reporting, and follow-up). Furthermore, we tried to determine the type of analytical procedures used by Croatian internal auditors. Firstly, we concluded that different groups of analytical procedures are not used equally in the internal auditors' assurance engagements. Related to that, we concluded that internal auditors most frequently use the identification of the missing numbers, duplication, validation of the date of entry $(93.2 \%)$ and individual financial ratios (71.6\%).

The contribution of the research is the assumption that internal auditors in Croatia respect required methodology regarding using analytical procedures, which leads to the conclusion that the state of internal auditing in Croatia is aligned with a global progress of the profession. An important observation is that the level of using analytics in all phases of assurance engagements is higher in Croatia compared to Asia-Pacific area, Europe and North America. However, as the results show, it is impossible to neglect the fact that Croatian 
internal auditors mostly use very simple and simple analytics. In addition to that, a more detailed analysis of using analytical procedures in different phases of assurance engagements suggests a need for significant improvement and a need for higher integration degree of the analytics in later and final phases of assurance engagements.

The results point out the lack of understanding and knowledge of the way analytical procedures should be used in latter phases and highlight the need for additional education of internal auditors - there exists a need for methodological improvement in performing engagements. In addition to the need for methodological improvement of auditing, the results show a need for additional education in the field of understanding and using different types of analytical procedures. Internal auditors are prone to use very simple and simple procedures, but they rarely use complex procedures that have the potential to significantly save limited time, human and financial resources, and consequently increase effectiveness and efficiency of internal auditing.

The final result shows that internal auditors in Croatia are not 'contemporary' and can be considered 'traditional'. A 'traditional' Croatian internal auditor uses simple analytical procedures, predominately in planning and performing phases of assurance

\section{References}

1. Act on Pension Insurance Companies. Official Gazette, 22/2014. Retrieved 2017, December 22, from https:// narodne-novine.nn.hr/clanci/sluzbeni/2014_02_22_399.html,

2. Alternative Investment Funds Act. Official Gazette, 16/2013, 143/2014, engagements. In that context, it can be concluded that the education system, scientists, regulators, and the profession must raise awareness of the importance and potential of using analytical procedures in assurance engagements as a valuable technique for increasing effectiveness and efficiency of internal auditing in Croatia.

The perspectives of using analytics in internal auditing in Croatia can be compared to global trends. As it is found by the research, the state of the analytical procedure application can be placed on the starting phase considering the fact that auditors mostly use simple procedures processed with MS Excel. In that context, perspectives include higher implementation level of the ERP systems in a business environment of companies that will supply internal auditors with more detailed data, and the ability to switch from samples to auditing data populations. Furthermore, the perspectives include integrating internal auditors' software with the ERP systems that will enable auditing data directly from companies' system. Next important step will include the ability of auditors to deal with big data. In that phase, the use of advanced analytics will be inevitable and necessary. To be able to do that, internal auditors need to obtain appropriate knowledge regarding technology application, and understanding analytics.

21/2018. Retrieved 2017, December 22, from https://narodne-novine.nn.hr/ clanci/sluzbeni/2013_02_16_265.html, Article 47.

3. Appelbaum, D., \& Kogan, A. (2017). Big Data and Analytics in the Modern Audit Engagement: Research Needs. Auditing: A Journal Of Practice \& Theory, 36(4), 1-27. doi: 10.2308/ajpt-51684 
4. Banarescu, A. (2015). Detecting and Preventing Fraud with Data Analytics, Emerging Markets Queries in Finance and Business. Procedia Economics and Finance 32, 1827-1836.

5. Bejaković, P., Vukšić, G., \& Bratić, V. (2011). Veličina javnog sektora u Hrvatskoj. Hrvatska $i$ komparativna javna uprava, 11(1)), 99-125. Retrieved 2017, December 20, from https://hrcak.srce.hr/file/195648

6. Bizarro, P. A., \&Garcia, A. (2011). SeQueL, the Other Audit Tool - Part II: Data Visualization and Analysis. Internal Auditing, 26(5), 16-20.

7. Braun, R. L., \& Davis, H. E. (2003). Computer-assisted audit tools and techniques: analysis and perspectives. Managerial Auditing Journal, 18(9), 725-731.

8. Brown-Liburd, H., Issa, H., \& Lombardi, D. (2015). Behavioral implications of big data's impact on audit judgment and decision making and future research directions. Accounting Horizons 29(2), 451-468.

9. Byrnes, P. E., Criste, T. R., Stewart, T. R., \& Vasarhelyi, M. (2015). Reimagining Auditing in a Wired World. In Audit Analytics and Continuous Audit: Looking Toward the Future (pp. 87-102).New York, USA: American Institute of Certified Public Accountants. Retrieved 2018, June 6, from https://www.aicpa.org/interestareas/frc/assuranceadvisoryservices/ downloadabledocuments/auditanalytics_lookingtowardfuture.pdf

10. Cangemi, M. P. (2016). Views on Internal Audit, Internal Controls, and Internal Audit's Use of Technology. EDPACS, 53(1), 1-9.

11. Caratas, M. A., \& Spatariu, E. C. (2014). Contemporary Approaches in
Internal Audit. Procedia Economics and Finance, 15, 530-537.

12. Chan, D. Y., \& Kogan, A. (2016). Data Analytics: Introduction to Using Analytics in Auditing. Journal of Emerging Technologies In Accounting, 13(1), 121-140. doi: 10.2308/ jeta-51463.

13. Coderre, D. (2015). Gauge Your Analytics. Internal Auditor 72(4), 39-45. Retrieved from https://iaonline. theiia.org/2015/gauge-your-analytics

14. Credit Institutions Act, Official Gazette, 159/2013, 19/2015, 102/2015. Retrieved 2017, December 22, from https://narodne-novine.nn.hr/clanci/ sluzbeni/2013_12_159_3328.html

15. Davuzyan, N., \& Kavut, L. (2005). An Application of Data Envelopment Analysis to the Evaluation of Audit Risk: A Reinterpretation. Abacus, 41(3), 290-306.

16. Dhillon, I. S., \& D. S. Modha (2001). Concept decompositions for large sparse text data using clustering, Machine Learning, 42(1/2), 143-175.

17. EY. (2018). 15th Global Fraud Survey: Integrity in the spotlight - The future of compliance. Retrieved 2018, June 11, from http://www.ey.com/Publication/ vwLUAssets/EY_Global_Fraud_ Survey_2018_report/\$FILE/EY\%20 GLOBAL\%20FIDS\%20FRAUD\%20 SURVEY\%202018.pdf

18. Factoring Act, Official Gazette, 94/2014, 85/2015, 41/2016. Retrieved 2017, December 22, from https:// narodne-novine.nn.hr/clanci/sluzbeni/2014_07_94_1883.html

19. Fraser, I.A.M., Hatherly, D.J., \& Lin, (1997). An empirical investigation of the use of analytical review by external auditors. British Accounting Review, 29(1), 35-47. 
20. Gepp, A., Linnenluecke, M. K., O’Neill, T. J., \& Smith, T. (2018). Big data techniques in auditing research and practice: Current trends and future opportunities. Journal of Accounting Literature, 40, 102-115.

21. Glover, S. M., Jiambalvo, J., \& Kennedy, J. (2000). Analytical Procedures and Audit-Planning Decisions. Auditing: A Journal of Practice \& Theory, 19(2), 27-45.

22. Insurance Act, Official Gazette, 30/2015. Retrieved 2017, December 27, from https://narodne-novine.nn.hr/ clanci/sluzbeni/2015_03_30_611.html

23. International Monetary Fund. (2014). Government Finance Statistics Manual. Retrieved 2017, December 20, from https://www.imf.org/external/ Pubs/FT/GFS/Manual/2014/gfsfinal. pdf

24. Jans, M., Alles, M. G., \& Vasarhelyi M. A. (2014). A Field Study on the Use of Process Mining of Event Logs as an Analytical Procedure in Auditing. The Accounting Review, 89(5), 1751-1773.

25. Kesner-Škreb, M. (1993). Javna poduzeća. Financijska praksa, 17(1), 91-93. Retrieved 2017, December 20, from http://www.ijf.hr/pojmovnik/javna_poduzeca.htm

26. Kopotienko, T. Y. (2015). The use of analytical procedures in the internal audit of the restaurant business expenses. Visnik Žitomirškogo Deržavnogo Tehnologičnogo Universitetu. Ekonomični Nauki, 2(72), 127-136, http://visnik.knteu.kiev.ua/ files/2015/06/13.pdf

27. Koskivaara, E. (2007). Integrating Analytical Procedures into the Continuous Audit Environment. Journal of Information Systems and Technology Management, 3(3), 331-346.
28. KPMG. (2018). Internal audit: Threading the needle. Retrieved 2018, June 11, from https://assets.kpmg.com/ content/dam/kpmg/xx/pdf/2018/01/ internal-audit-threading-the-needle.pdf

29. Leasing Act, Official Gazette, 141/2013. Retrieved from https:// narodne-novine.nn.hr/clanci/sluzbeni/2013_11_141_3011.html,

30. Li, H., Dai, J., Gershberg, T., \& Vasarhelyi, M. A. (2018) Understanding usage and value of audit analytics for internal auditors: An organizational approach. International Journal of Accounting Information Systems, 28, 59-76.

31. Lindow, P.E., \& Race, J.D. (2002). Beyond traditional audit techniques. Journal of Accountancy, 194(1), 28-33.

32. Marks, N. (2009). The Search for Meaningful Dana: Leveraging Data Analysis Software. Internal Auditor, 8, 35-38.

33. Messier, Jr., W. F. (2010). Opportunities for Task-Level Research within the Audit Process. International Journal of Auditing, 14, 320-328. doi: 10.1111/j.1099-1123.2010.00420.x, p. 322 according to: Trompeter, G., \&Wright, A. (forthcoming). 'The world has changed; have analytical procedure practices?' Working Paper, Northeastern University.

34. Ministry of Finance. (2017). Consolidated Annual Report on the Internal Control System in the Public Sector of Croatia for 2016 (Objedinjeno godišnje izvješće o sustavu unutarnjih kontrola u javnom sektoru Republike Hrvatske za 2016.). Retrieved 2017, December 21, from http://www.mfin.hr/adminmax/docs/ Objedinjeno\%20GI\%20za\%202016. pdf 
35. Ministry of Finance, Available 2017, December 21, athttp://www.mfin.hr/ $\mathrm{hr} /$ financijska-izvjesca-javna-poduzeca-2016

36. Moolman, A. M. (2017). The Usefulness Of Analytical Procedures, Other Than Ratio And Trend Analysis, For Auditor Decisions. International Business \& Economics Research Journal, 16(3), 171-184.

37. PricewaterhouseCoopers Risk Services Pte. Ltd. (2018). State of the Internal Audit Profession. Retrieved 2018, June 11, from https://www.pwc.com/sg/en/ publications/assets/state-of-the-internal-audit-2018.pdf

38. Protiviti's Research. (2018). Analytics in Auditing Is a Game Changer. Retrieved 2018, June 11, from https://www.protiviti.com/sites/default/ files/2018-internal-audit-capabilitiesand-needs-survey-protiviti.pdf

39. Public Internal Control Act. Official Gazette, 78/2015. Retrieved 2017, December 21, from https:// narodne-novine.nn.hr/clanci/sluzbeni/2015_07_78_1492.html.

40. Richins, G., Stapleton, A., Stratopoulos, T. C., \& Wong, C. (2017). Big Data Analytics: Opportunity or Threat for the Accounting Profession?. Journal of Information Systems, 31(3), 63-79.

41. Rulebook on Internal Audit in Public Sector. Official Gazette, 42/2016. Retrieved 2017, December 21, from https://narodne-novine.nn.hr/clanci/ sluzbeni/2016_05_42_1092.html

42. Rulebook on the on organisational requirements for pension companies managing mandatory pension funds. Official Gazette, 103/2014, 39/2017. Retrieved 2017, December 22, from https://narodne-novine.nn.hr/clanci/ sluzbeni/2014_08_103_2008.html
43. Rulebook on the on organizational requirements for UCITS management companies. Official Gazette, 41/2017. Retrieved 2017, December 22, from https://narodne-novine.nn.hr/clanci/ sluzbeni/2017_04_41_936.html

44. Rulebook on the organisational requirements for pension companies managing voluntary pension funds. Official Gazette, 103/2014, 41/2017. Retrieved 2017, December 22, from https://narodne-novine.nn.hr/clanci/ sluzbeni/2014_08_103_2009.html

45. Singh, N., Cheng, E., \& Lai, K.H. (2017). A Data Analytics - Based Approach to Auditing. Internal Auditing, 7/8, 33-41.

46. Soileau, J., Soileau, L., \& Sumners, G. (2015). The Evolution of Analytics and Internal Audit. EDPACS, 51(2), 10-17. doi: 10.1080/07366981.2015.1012441

47. Sparks, D. E. (2010). More Power for Internal Audit. Accounting Today, 24(7), 14-15.

48. Spencer Picket, K. H. (2003). The internal auditing handbook. $2^{\text {nd }}$ Edition. Hoboken, NJ, USA: John Wiley \& Sons.

49. Tang, F., Strand Norman, C., \& Vendrzyk, V. P. (2017). Exploring perceptions of data analytics in the internal audit function. Behaviour \& Information Technology, 36(11), 1125-1136.

50. The Croatian Financial Services Supervisory Agency (Hrvatska agencija za nadzor financijskih usluga). Register of credit institutions. Available 2017, December 22, at http://www. hanfa.hr/trziste-osiguranja/registri/ kreditne-institucije/?page=1.

51. The Institute of Internal Auditors. (2011). The International Professional Practices Framework (IPPF): Supplemental Guidance: Assisting 
Management, Vol. 23, 2018, No.2, pp. 15-46

A. Ježovita, B. Tušek, L. Žager: THE STATE OF ANALYTICAL PROCEDURES IN THE...

Small Internal Audit Activities in Implementing the International Standards for the Professional Practice of Internal Auditing where small internal audit activity. Retrieved 2018, March 19, from https:// na.theiia.org/standards-guidance/ Member\%20Documents/11188 PROFAssistingSmIAActivities_PG-FNLCX.pdf

52. The Institute of Internal auditors. (2011). Supplemental Guidance. Global Technology Audit Guide (GTAG). Data Analysis Technologies. Retrieved 2018, March 9, from https:// na.theiia.org/standards-guidance/recommended-guidance/practice-guides/ Pages/Practice-Guides.aspx.

53. The Institute of Internal Auditors. (2016). The International Professional Practices Framework (IPPF). The International Standards for the Professional Practice of Internal Auditing. Retrieved 2018, March 8, from https://na.theiia.org/standardsguidance/Public\%20Documents/IPPFStandards-2017.pdf

54. The Institute of Internal Auditors. (2016). The International Professional Practices Framework (IPPF). Implementation Guidance. Retrieved 2018, March 8, from https://na.theiia. org/standards-guidance/Member $\% 20$ Documents/2017-ImplementationGuides-ALL.pdf

55. Trompeter, G., \& Wright, A. (2010). The World Has Changed-Have
Analytical Procedure Practices? Contemporary Accounting Research, 27(2), 669-700.

56. Tušek, B., Žager, L., \& Barišić, I. (2014). Interna revizija. In: Tušek, B. Zagreb: Hrvatska zajednica računovođa i financijskih djelatnika.

57. Vunchnich, A. (2008). Using CAATTs in Preliminary Analytical Review to Enhance the Auditor's Risk Assessment. The CPA Journal. 78(5), 38-40.

58. Wadhawan, A., \& Mahajan, R. (2016). Detecting and managing operational, transactional and auditing risk using data analytics. 5th International Conference on Reliability, Infocom Technologies and Optimization (Trends and Future Directions) (ICRITO), Noida, 7-9 September 2016, 171-174. doi: 10.1109/ICRITO.2016.7784947

59. Wang, T., \& Cuthbertson, R. (2015). Eight Issues on Audit Data Analytics We Would Like Researched. Journal of Information Systems, 29(1), 155-162.

60. Yoon, K., Hoogduin, L., \& Zhang, L. (2015). Big Data as Complementary Audit Evidence. Accounting Horizons, 29(2), 431-438.

61. Zinca, C. I. (2016). Major trends of the Internal Audit Function in Credit Institutions. The USV Annals of Economics and Public Administration, $16(2 / 24), 137-144$. 


\section{STANJE ANALITIČKIH PROCEDURA U INTERNOJ REVIZIJI KAO ALATA KORPORATIVNOG UPRAVLJANJA}

\begin{abstract}
Sažetak
Interni revizori se suočavaju s brzo promjenjivim poslovnim okruženjem, koje ih potiče na implementaciju odgovarajućih informacijskih tehnologija te korištenje analitičkih procedura kao ključne revizijske tehnike. Stalni tehnološki napredak djeluje na razvoj i promjene analitičkih procedura, koje su bile nezamislive $u$ vrijeme "papirnate" revizije. Temeljna istraživačka ideja odnosi se na utvrđivanje razine i unapređenja analitičkih procedura, koje koriste interni revizori, $u$ suvremenim uvjetima poslovanja $u$ Hrvatskoj. S obzirom da napredak informatičke tehnologije podupire primjenu kompleksne analitike, istraženi problem uključuje analizu koherentnosti između raspoložive tehnologije i primijenjenih analitičkih procedura. Značaj korištenja analitičkih procedura može se potvrditi pozitivnim efektima, koje iste imaju na internu reviziju, $s$ obzirom na povećanje efektivnosti i efikasnosti revizije. U odnosu na navedeno, istraživanje, također, uključuje analizu razine, razlika $i$ složenosti analitičkih procedura, korištenih u internoj reviziji, kako bi se utvrdilo postojeće stanje i unaprijedili efektivnost te efikasnost interne revizije u Hrvatskoj. U odnosu na svrhu i mogućnosti analitičkih procedura, u radu se istražuje razina do koje se funkcija interne revizije u Hrvatskoj,
\end{abstract}

mjereno razinom primjene analitičkih procedura, prilagođava suvremenim poslovnim uvjetima $i$ promjenjivim poslovnim procesima. Istraživačka se pitanja analiziraju na temelju pregleda teorije, vodiča profesionalne prakse i značaja, koji se može pripisati internoj reviziji kao mehanizmu korporativnog upravljanja. Istraživanje pruža uvid $u$ djelovanje $i$ razinu primjene zahtijevane metodologije te procjenu o napretku hrvatske interne revizije u suvremenom okruženju. Napredak interne revizije u Hrvatskoj će se utvrditi usporedbom rezultata istraživanja s globalnim stanjem revizorske profesije. Nadalje, istraživanjem se utvrđuju perspektive napretka interne revizije $u$ odnosu na znanje $i$ vještine internih revizora, koje zahtijeva suvremena informacijska tehnologija. Također se utvrđuju i kompetencije revizora za korištenje kompleksnih analitičkih metoda u revizorskom poslu. Istraživački podaci su prikupljeni korištenjem ankete, a prikupljeni su odgovori analizirani korištenjem odgovarajućih statističkih metoda (frekvencije, proporcije, hi-kvadrat, Kruskal-Wallisov, Man-Whitneyev $U$, Kolmogorov-Smirovljev $i$ Shapiro-Wilkovi testovi).

Ključne riječi: analitičke procedure, analiti$k a$, interna revizija, interni revizori 